\title{
THE EVIDENCE OF THE AVANT-GARDE FILM
}

\author{
KÁROLY KÓKAI \\ University of Vienna \\ karoly.kokai@univie.ac.at
}

\begin{abstract}
The Hungarian neo-avant-garde appeared in such diverse artistic fields as fine art, conceptual and visual literature, happenings, theatre performance and film. For the avant-gardists Tibor Hajas, Miklós Erdély and Tamás Szentjóby, film was both a theoretical and a practical issue. There are films documenting avant-garde activities, and there are films that are truly avant-garde. Thus, the field of film seems to provide a considerable amount of material through which scholarship can evaluate the Hungarian neo-avant-garde. This paper discusses how the evidence of film fits the interpretation of the Hungarian neo-avant-garde as belonging to the "second public”, as part of cultural opposition, and as something forbidden.
\end{abstract}

Keywords: Avant-garde, Avant-garde Film, Cold War, Eastern Bloc, Tamás Szentjóby, Kentaur

Films are called documentary if they make heavy use of visual and sound sequences showing non-professional actors in their everyday environment, or even an environment without any human actors. Films of this kind aim to reveal the "strange worlds" of their subjects, showing how something "really is". Of course it is well known that this approach can never achieve its goal. All films are by definition artificial, and it is impossible to avoid the influence of the filmmakers. This is why the dividing „line” between documentary and fiction film is never a sharp one, and it is better to understand the documentary as a genre of fiction than to try to argue that both constitute two entirely different categories. ${ }^{1}$

Avant-garde film is an ongoing discussion, with new arguments arriving with every new avant-garde wave; the central issue of each is mostly to challenge everything established and traditional, and hence the past avant-gardes too. It has been argued that experimental, independent (in the sense of not being part of the movie industries), underground (in the sense of representing so-called deviant or at least sub-culture circles), counter culture, non-mainstream, non-commercial films are avant-garde. ${ }^{2}$ Certain film groups appeared with manifestos ${ }^{3}$ and therefore fulfilled one of the criteria of the avant-garde. Thus, there are numerous reasons to talk about avant-garde film. But perhaps we should recall that at the time of its invention, around 1895, film was genuinely avant-garde: technically new and thus experimental, exploring new and unknown artistic territories, pushing 
the limits, and creating a new art form. The few avant-gardists of the laboratory of Thomas Alva Edison ${ }^{4}$ were followed very soon by the garde of the film makers of subsequent generations.

While documentary film flourished in the Eastern Bloc of the 1960s, 1970s and 1980s, avant-garde film could exist only in a limited sense. Since film-making is a technically complicated process - technical equipment is needed to make the film, a chemical laboratory to process analogue film -, a crew is usually involved, including artistic and technical personal as well as actors, and since film is a timebased art, which usually means that making and viewing a film is a sophisticated process, so-called amateur artists have very little chance of being able to make a film, especially in the Cold War period in the Eastern Bloc.

Nevertheless, numerous avant-garde films were made in Yugoslavia, Poland, Romania, Czechoslovakia and Hungary, some of the most prominent being: Naško Križnar Nadstavba (Superstructure) 1966 Yugoslavia, Věra Chytilová Sedmíkrasy (Daisies) 1966 Czechoslovakia, Dušan Makavejev Misterije organizma, W.R. (W.R.: Mysteries of the Organism) 1971 Yugoslavia, Pawel Kwiek 1, 2, 3... ćwiczenia operatorskie (1, 2, 3... Cinematographer's Exercises) 1972 Poland, Zelmir Zilnik Crni film (Black Film) 1971 Yugoslavia, Ion Grigorescu Boxing 1977 Romania, Petr Skala Hledaní rovnovahy (Searching for Balance) 1973 Czechoslovakia, Sanja Iveković Osobni rezovi (Personal Cuts) 1982 Yugoslavia or Pavel Barta Mat (Checkmate) 1983 Czechoslovakia. To name a few films from Hungary: Dóra Maurer Megtanult önkéntelen mozdulatok (Perfunctory Movements) 1973, Miklós Erdély Partita 1974, Gábor Bódy Négy bagatell (Four Bagatelles) 1975, László Najmányi A császár üzenete (The Message of the Emperor) 1975, Tamás Szentjóby Kentaur 1975, Tibor Hajas Öndivatbemutató (Self-Fashion Show) $1976 .{ }^{5}$ The coming into existence of each of these films has its own story, naturally. Nevertheless, we see it was possible to achieve what should have been impossible - in a schematic and retrospective interpretation, which for the sake of simplicity tends to paint matters black and white.

Even in the restricted situation of socialist Hungary of the 1960s and 1970s, there were different ways of making films. One was for a one-person crew to use amateur equipment. It was by this means that a 9-minute documentary film of the first Hungarian happening in 1966 came into being. The artist László Gyémánt was invited to the happening, took his small film camera and used three scrolls, each lasting 3 minutes. Today the film is available on youtube. The other possibility: state-founded film schools existed all over the Eastern Bloc, such as the Neoplanta Studio in Novi Sad, Yugoslavia, the Workshop of the Film Form in Łódź, Poland, and the Béla Balázs Studio in Budapest, Hungary.

The Béla Balázs Studio (BBS) was first founded 1959 by Pál Gerhardt for the promotion of the young filmmakers just finishing the film school. ${ }^{6}$ The focus was on screenings of Hungarian and not distributed foreign films, as well 
as on discussions and - as a project - the creation of films (short, $16 \mathrm{~mm}$, not for distribution). The BBS was reestablished in September 1960 and started to function in 1961.

The first thirty years of the BBS can be divided into four periods. This periodization does not mean that no other kind of films were made. Rather, it is based on the most productive, dominant and visible examples. The periods are 1. short films, 2. documentary or sociographical films, 3. experimental or avant-garde films, and 4. fictional films with "avant-gardistic" elements. In the third period, from the 1970s on, people were allowed to make films in the BBS without visiting the film academy, e.g. Tibor Hajas, Miklós Erdély and Tamás Szentjóby, the three most important avant-garde poets and artists of the 1960s, 1970s and 1980s in Hungary. Erdély's Partita and Szentjóby's Kentaur were made in the framework of the Film Language Program of the BBS, Hajas' Öndivatbemutató in the framework of the next project, the K3 Group, both organized by Gábor Bódy. As the previous list of periods illustrates, documentary and avant-garde films were made in the BBS. Thus we can ask how the two are related, or rather, and this is the central issue of this paper, what can we learn about the documentary by watching an avant-garde film.

To discuss this question, let us take a closer look at one of the avant-garde films produced in the framework of the Béla Balázs Studio, Tamás Szentjóby’s Kentaur 1975/2009. ${ }^{7}$

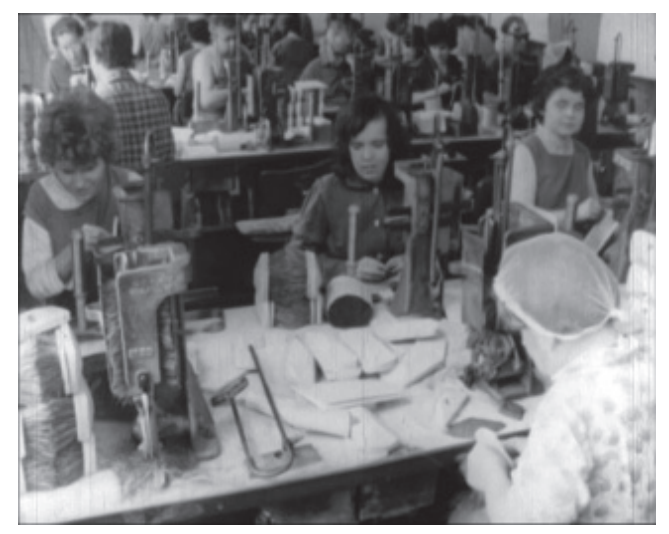

Kentaur consists of fourteen scenes: nature (sky and earth), railway (closed doors), sewing room, city bus, planning bureau, "presszó" (a kind of coffeehouse), fieldwork, canteen, constructing hall, lottery tickets sorting room, waiting room, paper box making hall, workers' home, and brush maker's workshop. Thus we see the world of the proletariat and the peasants. Each sequence starts with an establishing shot, the camera giving an extremely long and expansive view of 
the set. Than we see close ups and hear voices talking. Strange things are already happening during the long and static shots: we see balanced and well-composed pictures, with very few movements. We understand the scenery almost immediately, and we have to wait a relatively long time for a change. The time regime suggests something didactic or even doctrinaire. The next disturbing element is that the voices from the off and the visual information seem to be related but do not fit together entirely. We hear dialogues about the work what we see, but they are much more sophisticated, philosophical and ideological as that the voice could correspond with the picture. As the story unfolds, we see the same thing again and again, developing into an ironic, distancing, revealing and at the same time extremely realistic, disturbing and sad tableau. The last sequence shows blind women working in a brush maker's workshop and singing with happy faces a song about taking off to an unknown and fair land.

What is avant-garde in Kentaur 1975? First, the filmmaker. Second, the context in which the film came into being. Third, its reception. And naturally in terms of its features Kentaur fits into the avant-gardistic oeuvre of Tamás Szentjóby.

Szentjóby is considered one of the central figures of the Hungarian avant-garde of the 1960s and 1970s. He started out as a poet, making subversive and visual poetry, and he continued as an action artist and made objects. He organized the first happening in Hungary in 1966, he was an active participant in the avantgardistic circles in Budapest, and he repeatedly had problems with Hungarian official cultural politics. He was expelled from Hungary in late 1974; he had to leave the country within one year. During this year, 1975, he had his only exhibition in Hungary before 1989, ${ }^{8}$ and he finished his film Kentaur.

Kentaur was made in the framework of the Film Language Series of the Béla Balázs Studio in the period when avant-garde artists were accepted to make their films. Szentjóby submitted a short paper with his idea, and worked with the cameraman János Gulyás and the editor Éva Vörös for two years.

The film was finished in summer 1975, thus months after Szentjóby was informed of the decision to expel him from Hungary because of his involvement in the activities of dissident intellectuals. It was first shown in the BBS for the members of the studio collective and a second time in the projector room of the Hungarian Film Industries for a more general public. In the BBS, as Szentjóby recalls, the projection started, but only shaky and rattled pictures appeared on the screen. Szentjóby went to the machine room and found two men working in coats and hats. It proved that these two strangers had sent away the projectionist and tried to sabotage the screening or at least to control it. And since they did not know how to use the projector, the film was not inserted properly, which explains why the screening went wrong. The proper reception of the film was delayed until 2009, for more than thirty years. It was confiscated in summer 1975 and was found in 1983 by György Durszt, who copied it and transferred to video immedi- 
ately. Durszt showed the film in university courses before 2009 too. But the film of 1975 was only restored in 2009; the background sound, which had been lost, had to be reconstructed from tiny pieces of the voice record. Since then the film has been shown worldwide and has become part of the Hungarian avant-garde heritage of the 1970s.

Kentaur has the features of the avant-gardistic oeuvre of Szentjóby. It uses reduced and hence unambiguous formal means mixed with signs of protest in a provocative manner, something visible in all of his poetic, actionist and artistic works. Compared to the two other most-discussed Hungarian avant-gardists creating films, Hajas and Erdély, Szentjóby’s approach is unique too. He uses long shots, contrapositions picture and sound, and directs this basic means against core values of the established cultural regime.

A brief glance at the documentary and avant-garde film production of the BBS and a closer look at a film made there raise a number of questions.

What is Szentjóby's film about? For the title, Centaur, Szentjóby has a specific interpretation. In 1964 he wrote a poem by the same title; ${ }^{9}$ the idea of centaur seems to have occupied him since the beginning of his artistic production. According to Szentjóby, the figure of the centaur is a metaphor which shows how the world is basically structured. It is an epistemological metaphor that reveals the structure of the world - first of all the world of socialism but in reality our global situation - and it is a tool with which to interpret the film Kentaur too. The mythological figure of the centaur consists of two parts, the lower body of a horse and the upper body of a human. Thus we deal with a double consisting of two incongruous parts. This double is what Szentjóby is concentrating on: the horse represents the being, the given and objective, whilst the human represents the interpretation, the meaning, the function. This goes for everything and anything, for every object in the world, for instance a desk. A desk is first of all there in its being, like the horse. It is there as an object. So much for the first part, the lower half. But it is the function that humans give it that makes it a desk - the second part, the upper half of the centaur. In the case of the film, the picture is the horse. And the sound is what gives the film its meaning. Thus Szentjóby contraposes the image on the one hand and the sound on the other to be able to say something very basic about our world. The documentary-like images provide us with the objective world that is to be revealed.

If we consider the above mentioned periods of the BBS from the perspective of short films, sociography and experimental to feature films with experimental elements, the question arises how can we interpret Kentaur from this viewpoint? Szentjóby made use of documentary-like visual sequences, most of them looking like footage found from newsreels of the Stalinist period of the early 1950s. Its static and penetrating long shots seem to go in the same direction. Watching Kentaur decades later it is hard not to understand it as an ironic reference to the 
sociographical documentaries of the young BBS filmmakers, eager to correct the mistakes of the really existing socialism of their state.

Seeing Kentaur recently raises a question as to why one would restore the film in 2009 and show it in exhibitions and shows in Hungary and abroad? Has Kentaur any relevance to the present or is our interest only historical? What is important here is to recognize that the restored film of 2009 is a recent one, with new meanings. It has a nostalgic value. It reinterprets the socialist and thus past era. And: it creates a past that never existed - by documentary means.

At the same time, all of this, the film itself, the censorship story, the place of Kentaur in the avant-garde film production of the Eastern Bloc of the Cold War period, raises the question: what does this film document?

Kentaur asks what documentary films are, especially what the documentary films of the BBS stand for. Szentjóby uses (as a poet, as an artist, as a filmmaker) as little as possible (almost nothing) to achieve as much as possible in the poem Getting Dark (the blackness of the type writer), in the object Czechoslovakian Radio (a brick and sulfide), in the action Expulsion Exercise (sitting silently), and in the film Kentaur (found footage like film and sound). His strategy of using a reduced formal vocabulary can be interpreted in different contexts. It can be seen as a reaction to the socialist repression of culture: the less material you have, the more difficult it will be to persecute you. If you do almost nothing (if you fulfill an everyday act, if you show simple motives), it is difficult to prove that you did something subversive. On the other hand, it can be interpreted as a minimalist or concept art strategy, and thus as part of a contemporary art movement. And, thirdly, it can be interpreted as using everyday, documentary, that is objective pieces of reality to show exactly that: what is out there.

The evidence of the avant-garde film is first of all that we see what the avantgarde was. In 1966 Laszló Gyémánt’s Ebéd (Lunch) documented the happening with the same title. Kentaur used documentary-style sequences to uncover a double, a story unfolding before our eyes and a story told by the voices.

The Eastern European avant-garde left very little evidence and was considered provocative. What little evidence there is consists of photos (documenting events), samizdat publications, typed or handwritten texts, a few artworks between montage of found objects and what was left over from an art event, and a lot of retrospective stories and interpretations. Thus the question regarding the evidence of these films is more than apt: what are we seeing while watching an avant-garde film?

We are seeing a document of the Cold War period in the Eastern Bloc showing that it was possible to produce avant-garde films in state-funded and state-controlled institutions. The production, distribution and reception stories nevertheless emphasize how difficult it was to realize the project, what rejection by the cultural policies meant and how the distribution of the film was made impossible 
by means such as confiscation. This narrative naturally contains the next part too, namely how art objects became a legend. Since Kentaur was only screened twice in the years immediately following its release and completely invisible until 1983, there was sufficient time for rumours to develop. Between 1983 and 2009 only a fragmented version was in circulation, sustaining the legend regarding the original whole. This twenty-six-year period must be divided into two parts. In the six years before 1989, during the last years of Cold War Hungary, persecuted art objects like the scrolls of Kentaur symbolized an artistic heritage and an artistic milieu that was highly politicized and instrumentalized for the purposes of so-called criticism of the regime. After 1989 this narrative become the founding myth of a new open and democratic culture in Hungary as well as in other countries of the former Eastern Bloc.

In their content, form and techniques, avant-garde films are considered experimental, charged with politically and socially relevant ideas aiming at utopias. Hungarian avant-garde film of the Cold War period can be analyzed in these categories too. Szentjóby's Kentaur, as a film which at first glance matches the documentary practice of the young film makers' association BBS applies experimental means only unobtrusively. The contrasting of sound and image becomes clear during the screening only gradually. The social practices depicted are the preferred topics of the documentaries of the 1960s and 1970s: the everyday environment of the working class, the workplace itself, the breaks, travel to work or leisure activities afterwards. Again, the visual is experimental here only in very restrained fashion, for instance by means of the length of the individual parts, thus recognizable only after a delay - using the method of making conflicts conscious, something discussed by communist theoreticans from the 1920s on. And it is exactly that slow process of becoming aware of what is going on that becomes political, questioning the very foundations of the system of socialism. The argument amounts to a genuine depiction of the dreams of the proletariat, at the end of the film questioning the utopias of the twentieth century, be it the utopia of communism or that of the avant-garde.

After the system change of 1989, the established cultural narrative read the last two and a half decades, the period of the Kádár years since 1963, i.e. the formative years of the generation that 1989 received the opportunity to fill the available political and intellectual positions ${ }^{10}$ - as the establishment of a second public, ${ }^{11}$ which meant a public differentiated from the first, official one. According to this figure, a sharp line divided those who served the official culture and those who opposed it. This demarcation line concerned every aspect of the life of the actors, be it their education, culture - inventing the term counter culture -, social status, social life, travel possibilities, employment, involvement in publication projects or the opportunities to realize, exhibit and discuss their artistic output. At the same time it ignores the basic cultural achievement of the period, the compromise 
between the rulers and those being ruled. The authority made the offer for everyone to get opportunities in the system, and many accepted the offer by entering higher education institutions - where, to name just one aspect, it was impossible to avoid involvement in the activities of the communist youth organizations -, testing the limits via critique from the left (e.g. by using Maoist arguments) as well as from the right (e.g. by "inventing" elements of the contemporary Western bourgeois culture in the East).

The films of the avant-garde in the Eastern Block prove to be avant-garde in every respect. They use the institutional means provided by the state to transcend limitations. They use experimental practices in all aspects of content, form and technique. They unveil the realities of the world called real socialism. And they testify to the myths under construction.

\section{Notes}

1 For discussions on the division between documentary and fiction film see e.g. Rancière, Jacques, Le Partage du sensible: Esthétique et politique. Paris: La Fabrique 2000; on a definition what documentary films are see e.g. Nichols, Bill, Introduction To Documentary. Bloomington: Indiana University Press 2001.

2 See Gelencsér, Gábor red., 2009. BBS 50. Budapest: Mücsarnok.

3 E.g. The Free Cinema Manifesto 1956, Oberhausener Manifest 1962, Dogma 951995.

4 E.g. William Kennedy Dickson made films since 1891, the first sound film in 1895.

5 Some of these films or parts of them are available online, see e.g. Erdély, Miklós, Partita. 1974. https://www.youtube.com/watch?v=4rzhxxJTM64, Bódy, Gábor, Négy bagatell. 1975. https://www.youtube.com/watch?v=oAUSRaexQRE, Hajas, Tibor, Öndivatbemutató. 1976. https://www.youtube.com/watch?v=zRBLAZavqc0 [Accessed 5 May 2017]. Thus it seems to be possible to illustrate this paper with visual material. At the same time it is important to remark, that watching the above mentioned films online changes the artworks significantly, that is why Tamás Szentjóby e.g. rejects any permission of a public show of Kentaur using inadequate technical infrastructure.

6 Gelencsér 2009.

7 Beke, László, 1978. Kentaur. Szentjóby Tamás tanpályái (Centaur: Tamás Szentjóby’s Courses of Education). Magyar Mühely, 30 June, 16 (54-55), 66-91; Molnár, Gergely, 1978. Kentaur. Levél Szentjóby Tamásnak (Centaur. A Letter to Tamás Szentjóby) Magyar Mühely, 15 December, 16 (56-57), 18-26; Tábor, Ádám, 1983. Képrombolás - Kentaur (Picture Destruction - Centaur). Aktuális Levél, Summer, 5,15; György, Péter, 1990. A lázadás esztétikája. Kentaur (The Aesthetics of Rebellion. Centaur). Filmvilág, March, 33 (3), 16-19.

8 Club of the Young Artists Budapest April 25-May 8, 1975.

9 Összenéző / két idő // partjuk között / egy rejtett árny / fordul egyre beljebb // És felfelé / űzik a dalt a paták - Two times / watching each other // between their banks / a hidden shadow / turns inside // And the hooves / chase the song to the top.

10 To avoid misunderstandings: this is valid for all acteurs regardless what position they took in the political spectrum after 1989 , left, right or center.

11 See Knoll, Hans ed., 1999. Die zweite Öffentlichkeit. Kunst in Ungarn im 20. Jahrhundert (The second public. Art in Hungary in the $20^{\text {th }}$ century). Berlin: Philo Verlag. 